\section{International Scientific Journal Theoretical \& Applied Science}

\author{
p-ISSN: 2308-4944 (print) e-ISSN: 2409-0085 (online) \\ Year: $2016 \quad$ Issue: 4 Volume: 36 \\ Published: $30.04 .2016 \quad \underline{\text { http://T-Science.org }}$
}

SECTION 13. Geography. History. Oceanology. Meteorology.
Alexander Sergueevich Semenov

Ph.D., Bio Pharm Cluster «Northern», Department of Innovative Pharmaceuticals and Biotechnology, Moscow Institute of Physics and Technology,

Russian Federation semyonov1980@mail.ru

Vladimir Vladimirivich Bulat expert,

Deep Dive Research Group, Russian Federation buen_dia@mail.ru

\title{
ON THE ETHNIC AND LINGUISTIC SITUATION IN EURASIA IN IV-III MIL. BC ACCORDING TO MODERN PALEOGENETIC DATA
}

Abstract: The paper deals with the origins of the steppe population of Eurasia in IV-III mil. BC. The main conclusion is that it can be regarded as the mix of two origins, one of Nostratic language family and the other one of Sino-Caucasian family. The latter could be connected with R1 Y-DNA haplogroup spread.

Key words: Neolithic, haplogroup, Nostratic family, Sino-Caucasic family

Language: Russian

Citation: Semenov AS, Bulat VV (2016) ON THE ETHNIC AND LINGUISTIC SITUATION IN EURASIA IN IV-III MIL. BC ACCORDING TO MODERN PALEOGENETIC DATA. ISJ Theoretical \& Applied Science, 04 (36): 167-180.

Soi: http://s-o-i.org/1.1/TAS-04-36-29 Doi: crossef http://dx.doi.org/10.15863/TAS.2016.04.36.29

\section{О ЯЗЫКОВОЙ И ЭТНИЧЕСКОЙ СИТУАЦИИ В ЕВРАЗИИ В IV-III ТЫС. ДО Н.Э. ПО СОВРЕМЕННЫМ ДАННЫМ ПАЛЕОГЕНЕТИКИ}

Аннотация: В статье рассматривается вопрос происхождения населения европейских степей в IV-III тысячелетиях до н.э. Основным выводом является то, что его можно рассматривать как происходящее от двух корней, причем с лингвистической точки зрения один корень относится к ностратической семье, второй - к сино-кавказской. Именно со второй популяцией может быть ассочиировано распространение гаплогруппы $R 1$.

Ключевые слова: гаплогруппа, ностратическая семья, синокавказкая семья, неолит

Когда в начале XIX века было доказано существование индоевропейской языковой семьи (окончательно - Ф.Шлегелем и Т.Юнгом в 18081813 гг [1]) , возникла известная проблема несоответствия языкового единства (близости) и заметных антропологических различий между индоевропейскими народами, И если к концу ХХ века схема развития индоевропейской семьи значительно упростилась: большинство историков и лингвистов считали прародиной древнейших индоевропейских племен СреднеВосточную Европу (гипотеза ИвановаГамкрелидзе не пользовалась поддержкой большинства специалистов), то появление новой научной дисциплины - палеогенетики, сразу начало вносить коррективы в индоевропеистику как науку, сложившуюся в результате взаимодействия археологии и лингвистики и ставить новые вопросы.

В своей небольшой статье «О начальном этапе индоевропейской истории» [2]
А.Г.Козинцев рассматривает проблему проникновения инокультурных миграций в зону восточноевропейских степей III тысячелетия до н.э. и обратных связей степных культур с культурами карпатско-балканского региона, отмечает, что «время дивергенции анатолийских и прочих индоевропейских языков совпадет со временем первой миграции с Ближнего Востока на Северный Кавказ», следовательно, индоевропейский язык привнесен аборигенам степей с юга, и делает общий вывод: «Теория иентральноевропейской прародины индоевропейцев противоречит генетическим данным о резком отличии степного населения от подавляющего большинства изученных групп зарубежной Европь эпох неолита и ранней бронзыл».

Возражения Л.С.Клейна на статью А.Г.Козинцева «О начальном этапе индоевропейской истории» [там же] сводятся к утверждению, что «какая-то из двух «теорий» 
неверна:

либо

гипотеза «центральноевропейской прародине
индоевропейцев», либо лингвистические выводы из обнаруженных генетиками фактов» [3]. Обусловлено это тем, что А.Г. Козинцев утверждает, что «Теория центральноевропейской прародины индоевропейцев противоречит генетическим данным о резком различии между степным населением $и$ всеми изученными группами зарубежной Европь эпох неолита $u$ ранней бронзы» [2]. А.Г. Козинцев также утверждает относительно местонахождения комлекса Мешоко - отличного по своим характеристикам как от трипольских комплексов, так и от майкопских (а некоторыми исследователями определяемого как маркер продвижения кочевников восточноевропейских степей на запад [4, с 146-148], что «постепенная деградация керамического производства в Мешоко при том, что кремневая индустрия на позднем этапе, наоборот, переживает некий Ренессанс, свидетельствует о встрече двух резко различных культурных традиций» [2]. Таким образом, А.Г. Козинцев обозначил двусоставность индоевропейских популяций: 1) популяция, коренная для евразийских степей, сравнительно с пришельцами, 2) популяция, привнесшая индоевропейский язык. Таким образом, встает вопрос о корнях этих популяций. И накопленные палеогенетиками данные позволяют сформулировать некоторые предварительные гипотезы.

Что касается коренной для степей популяции- налицо присутствие в ней гаплотипа R1 и связь с Мальта-Буретинской культурой (палеолитическая находка Y-гаплогруппы R)[5, p 49]. Статистика присутствия субкладов R1 в Восточной Европе такова: в хвалынской культуре - R1a1, R1b1, Q (6), в Ямной культуре - 7 различных субкладов R1b [7, p 5, p 40], и по предварительным данным - 1 субклад R1a, в культуре Вучедол - 2 находки R1b [7]. Yхромосомная гаплогруппа R1a1 была выявлена у одного представителя культуры шнуровой керамики из Эсперштедта (Esperstedt, № I0104) [7, p 25] и у двух представителей из Эйлау (Eulau) [7, p 73] (там же - В Эсперштедте - в последнее время обнаружено в общей сложности 4 носителя субклада R1a, a также по одному носителю R1a1a, R1a1a1 и R1b1a2 - всего 8 вместе с носителем R1a1 [8]).В целом можно говорить, что «the most of the Corded Ware cultures are characterized by the steady dominance of Y-DNA R1a1 haplogroup...[9, p 173, 192]

Для понимания происхождения, второй, привнесенной популяции не следует упускать из вида и ностратическую гипотезу. В настоящее время в круг ностратических языковых семей с определенной вероятностью включены не только индоевропейцы с картвелами, уральцами, алтайцами и дравидами, но и т.н. палеоазиатские языковые семьи, продвинувшиеся к Тихому океану - на этом настаивает, например О.А.Мудрак [10].

И лингвистика также дает картину двусоставности индоевропейского языка. Еще в 1934 году профессор Эмиль Форрер из Швейцарии высказал мнение, что индоевропейский язык образовался в результате скрещивания двух неродственных языков [11], а Н.С.Трубецкой, Х.К.Уленбек и Б.В.Горнунг предполагали, что это скрещивание происходило между языком уральско-алтайского типа и языком типа «кавказско-семитского»[12]). Известный нидерландский лингвист Ф.Котландт относит индоевропейские, уральские языки и юкагирский язык к гипотетической уралосибирской языковой семье: «We may conclude that Proto-Indo-Uralic and Proto-Altaic may have been contemporaries (6000-5500), that Proto-Uralic and Proto-Uralo-Yukagir may have been the same thing and contemporaneous with Proto-Indo-Hittite (45004000), and that Proto-Finno-Ugric and nuclear Proto-Indo-European may again have been contemporary languages (3500-3000). This puts the dissolution of the Uralo-Siberian language family in the 7 th millennium. It now becomes attractive to identify the latter with the abrupt climate change of 8200 BP or 6200 BC, when severe cold struck the northern hemisphere for more than a century. The catastrophic nature of this disastrous event agrees well with the sudden dispersal and large-scale lexical replacement which are characteristic of the Uralo-Siberian languages».[13, p 4]. Аналогичного мнения придерживается Г.А.Старостин:

«Kassian, Zhivlov, Starostin 2015: an attempt to find a favorable statistical signal for Indo-Uralic based on most thoroughly refined lexical evidence

- «Swadesh list» reduced to a smaller set of 50 most stable elements as determined by the procedure in [S. Starostin 2007]

- «optimal candidates» filtered out of the corpus of IE / Uralic reconstructions

- potential matches automatically established based on comparison of the words' consonantal structures (the "Dolgopolsky method»)

- statistical significance of the results is tested by the application of the "permutation test» [Baxter \&Manaster-Ramer 2007]» [14, p 8].

В майкопской культуре-протоцивилизации (а это говорит, в принципе, о ее сложности и многосоставности) наряду с коренным населением выделяют как южную компоненту, 
так и северную. Последняя - новосвободненская культура, чье происхождение связано с миграциями из Центральной Европы - т.е. из-за пределов степного ареала: «из области мегалитических культур воронковидных кубков» - это утверждает Л.С. Клейн [15, с 73]). Южная же компонента связана с влиянием на майкопскую протоцивилизацию убейдо-урукских элементов Двуречья [16, с 101, 106, 108, 112].

С какими бы лингвистическими группами не связывался новосвободненский компонент происхождения, факт миграции северносреднеевропейских европейских общностей на юго-восток (к степи и через нее) уже подтверждается генетически. С северными группами новосвободненцев связывает наличие митохондриальной гаплогруппы $\mathrm{V}$ (точнее субклада V7 [17, с 34-38]) - достаточно редкой в наше время, и во многом сконцентрированной на севере Европы - в саамском ареале. А ранее наблюдается движение митогаплогруппы V из Западной Европы на Северо-Восток. В финальном палеолите мы обнаруживаем носителей V в культуре Мадлен [18, p 1146]. Далее - уже в неолитическую эпоху - mtDNA V обнаружен в рессенской, зальмюндской культурах и культуре линейно-ленточной керамики - все V тысячелетие до н.э. [19, р 9596]. Рессенская культура является переходной от широко распространённой традиции культуры культуры линейно-ленточной керамики, восходящей к раннему неолиту Европы, к более разнообразным культурам среднего и позднего неолита, таким, как м ихельсбергская и культура воронковидных кубков (первая является потомком рёссенской - через посредничество группы Бишхайм 4400-4200 гг. до н. э., вторая скорее инвазивной, занявшей крайний северовосток бывшего Рёссена[20]). А далеко на северо-востоке Евразии V была с определенной достоверностью выявлена в останках Жоховской стоянки на Новосибирских островах - (кон.VII-VI тысячелетия до н.э.) [21, с 67].

Связь франко-кантабрийского региона с севером Европы в финальном палеолите и мезолите происходила не только по территории современной европейской суши, но и через довольно крупный массив суши на месте современного Северного моря, а поэтому вполне вероятно прямое попадание носителей гаплогруппы V в Скандинавию через территорию т.н. Доггерланда [22, p 98-102, р 277]. В статье [23] прямо указывается на соответствующие генетические маркеры как на обозначение данной миграции: «Furthermore, their frequency patterns and ages resemble those reported for haplogroup $V$ (Torroni et al. 2001a)—which, similar to U5b1b, is extremely common only in the Saami (together, $U 5 \mathrm{blb}$ and $V$ encompass almost $90 \%$ of the Saami mtDNAs) (Torroni et al. 1996; Tambets et al. 2004)》 [23, p 885]. Таким образом, генетические предшественники новосвободненцев могли присутствовать в потоке миграции от франкокантабрийского региона на Север Европы и далее в сибирскую Арктику, который проходил через территорию будущего ареала культуры воронковидных кубков (присутствие гаплогруппы K на мезолитическом Готланде и на Жоховской стоянке лишь подкрепляет предположение) .

Надо заметить, что мысль А. Г. Козинцева о привнесенности индоевропейского языка в степь, и ответ Л.С. Клейна, указывающий на северозападное направление, оставляет открытым вопрос о направлении привнесения индоевропейского языка - северо-западное или южное. Однако, если вовлечь «ностратический аргумент», то возникает парадокс - и Л.С. Клейн, и А.Г. Козинцев говорят, что инодоевропейский праязык привнесен с запада Евразии. Тогда как ностратический подход говорит и о восточных связях (вплоть до Чукотки). Если принять точку зрения о западноевразийской прародине индоевропейского языка, то данные палеогенетики позволяют наметить пути к снятию противоречия. Это, возможно, если предположить, что ностратические языки распространялись на восток Евразии с носителями U4, U5a, K, V. Взаимосвязи культур на просторах Евразии прослеживаются по наличию определенных субкладов, а именно 7 образцов mtDNA K (а также V) на вышеупомянутой Жоховской стоянке [21, с 67]. Субклады U5 обнаруживаются в Чекалино (возраст - 7800 лет до н.э.; [24, р 137-140]), Лебяжинке (возраст - VIII-VII тысячелетия до н.э; там же), а, и что особенно важно, восточнее в Китойской культуре (возраст - 6100-4900 до н.э.; [25, p 44]), но все они младше самых древних европейских находок U5 - например в Blätterhöhle, Germany (возраст - 8700-8600 до н.э.; [26, р 480]), и V - в Северной Африке и Испании, что указывает на Западную Евразию как на исходную зону расселения носителей этих гаплогрупп. В могильниках усть-тартасской культуры междуречья Оби и Иртыша и еe потомков обнаружен целый набор mtDNA раннеметаллической эпохи: $2 \mathrm{~A}, 4 \mathrm{C}, \mathrm{D}, 3 \mathrm{U} 2 \mathrm{e}, \mathrm{U} 4$, 2U5a1, 4Z [27, p 109], а также неолитического периода: 2U2e, Z [28, с 64-65]. Учитывая возможный алтайский характер китойской культуры, можно сделать предположение, что гаплогруппа U5а могла быть в среде праалтайцев, a обнаруженные на Жоховской стоянке $\mathrm{K}, \mathrm{V}$ могли маркировать протоэскимосов, по мнению 
Мудрака, связанных с праатлайцами: «K настоящему времени обнаружено около 1200 алтайско-эскимосских этимологий» [10]. Распространение указанных гаплогрупп позволяет предположить, что Жоховская стоянка может относиться к ареалу палеазиатских языков, а зона усть-тартасской и китойской культур и, возможно, Чекалино - к уральским или алтайским. Таблицы 1-3 Приложений показывают распространение гаплогрупп U5a, $\mathrm{U} 5 \mathrm{~b}, \mathrm{~V}$, с запада на восток, причем западные находки древнее. Данные таблицы демонстрируют опорные точки миграционных на просторах Евразии, и то, что митохондриальные субклады U5a сумели продвинуться на Восток очень далеко.

На севере Европы останцем мигрировавших по путям распространения U5b и Vгрупп ностратиков могут быть саамы (точнее, некоторые, возможно, средние по возрасту слои саамского населения). Саамское население Северной Европы также является носителем субкладаU5b1b (вместе с V носители U5b1b составляют 90\% саамского населения [23, р 885]), причем, есть основания считать, что в саамскую среду данный субклад проник из СевероЗападной Африки или Западной Европы (там же).

C позиций палеогенетики индоевропейскоуральские также связи вполне объяснимы. Маркеры митохондриальной ДНК U4 присутствуют в ямной (субклад U4a1; [7, p 25; 29, s 7, 176]) и шнуровой [30] культурах (т.е., в культурах, чья принадлежность к индоевропейским племенам признается практически всеми археологами). СубкладU4a2 или U4d обнаружен у представителя хвалынской культуры, жившего 6700 лет назад [8]. В равной степени U4 распространена в уралоязычных археологических культурах на Волге и на Урале [31, p 1758-1762]. U4 присутствует в т.н. постсвидерских культурах, население которых часто связывается с носителями уральских или парауральскихязыков, - в культурах Кунда [24, p 139], Веретье [32, p 4] и на Большом Оленьем Острове (субкладU4a1; [там же]). Постсвидерский характер данных культур признается авторами академического атласа Tartarica [33, с 72]. Хотя вопрос об истоках миграций, привнесших в восточноевропейскую степь индоевропейский праязык остается открытым, в любом случае близость индоевропейской и уральской семей в рамках ностратической языковой общности указывает на близость их прародин (наличие гаплогрупп U4 и U5 говорит в пользу североевропейской прародины, а если все же подтвердится южное происхождение индоевропейских племен, близость их праязыка к уральскому объяснима гипотезой о влиянии свидерской культуры на тахунийскую культуру Палестины [34].

Что же касается исходного этнического фона, на который накладывались волны мигрантов в степи Восточной Европы, то нам представляется, что при изучении истоков индоевропейцев недооценненным остается мезои неолит азово-каспийской области (см. карта 2). Т.н. Мариупольская общность (или иначе азовокаспийская неолитическая общность) сформировалась в эпоху раннего неолита путем миграций в восточноевропейские степи населения с юга и юго-востока - т.е. с берегов Каспийского моря, куда предки мигрантов проникли из еще более южных районов в мезолите: из районов зарзийского культурного комплекса и постнатуфийской культуры Ближнего Востока. Среди культур этого круга выделяется в качестве одной из самых ранних средневолжвкая или даже елшанская культура, в которой обнаружена мужская гаплогруппа R1b1 $[35$, c 13]. 


\begin{tabular}{|c|c|c|c|c|c|c|}
\hline Impact Factor: & $\begin{array}{l}\text { ISRA (India) } \\
\text { ISI (Dubai, UAE } \\
\text { GIF (Australia) } \\
\text { JIF }\end{array}$ & $\begin{array}{r}=1.344 \\
=0.829 \\
=0.564 \\
=1.500\end{array}$ & $\begin{array}{l}\text { SIS (USA) } \\
\text { PИHЦ (Russia) } \\
\text { ESJI (KZ) } \\
\text { SJIF (Morocco) }\end{array}$ & $\begin{array}{l}=0.912 \\
=0.234 \\
=1.042 \\
=\mathbf{2 . 0 3 1}\end{array}$ & $\begin{array}{l}\text { ICV (Poland) } \\
\text { PIF (India) } \\
\text { IBI (India) }\end{array}$ & $\begin{array}{l}=6.630 \\
=1.940 \\
=4.260\end{array}$ \\
\hline
\end{tabular}

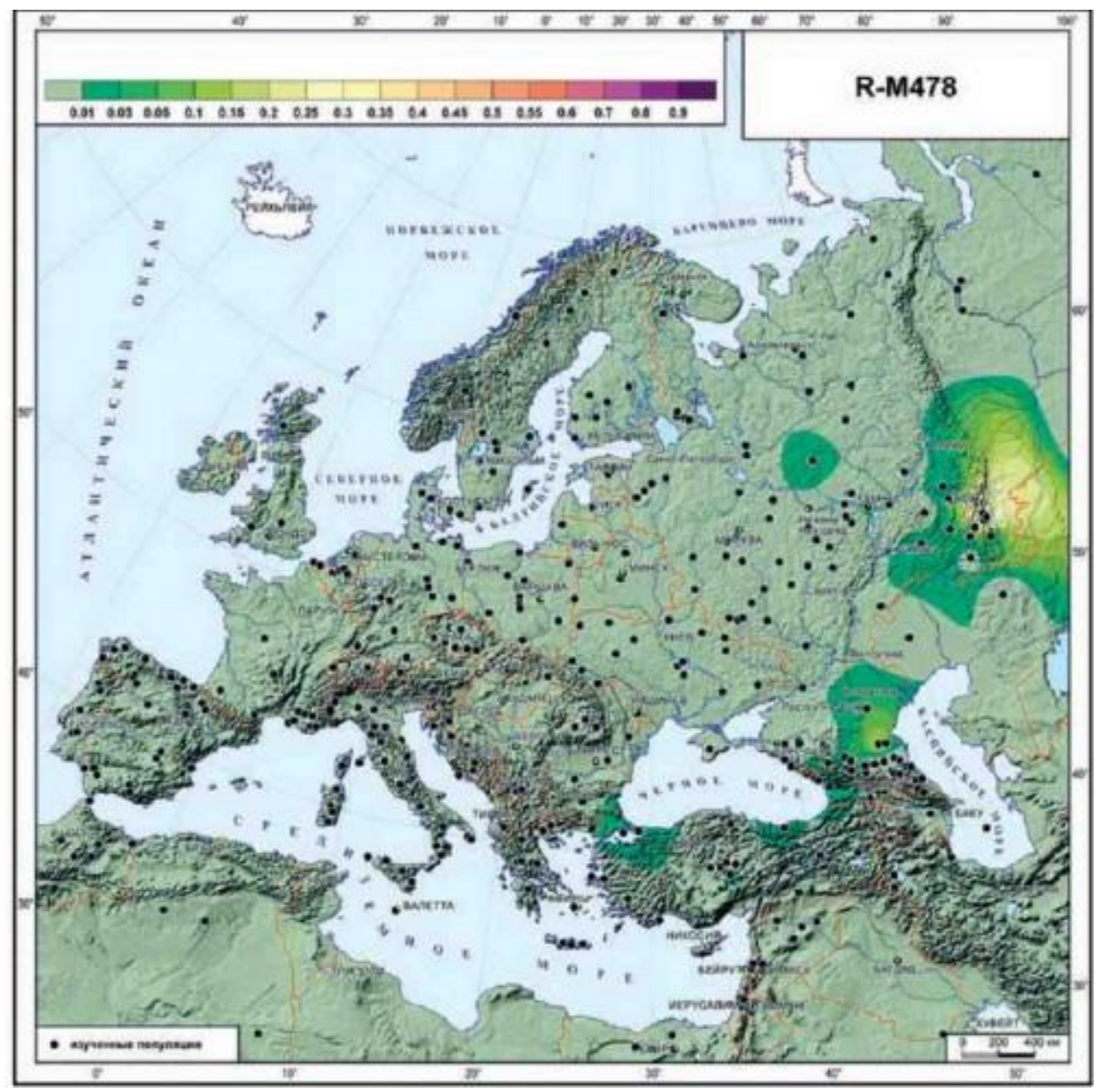

Карта 1. География гаплогруппы R1b-M478 Y-хромосомы в Европе [36].

Образец R1b1 Лебяжинка IV имеет маркер preR-M478 [7, p 25], тогда как R1b-M478 все еще рааспространена неподалеку от елшанского ареала.

Впрочем, зарзийские племена, вероятнее всего, говорили на синокавказских языках родственных кетскому, бурушаски, или языкам, чья принадлежность к синокавказским дискутируется - хаттскому и хурритском [37, с. 317-318, 339, 343]. При этом не исключено наличие синокавказского субстрата и в языках ближневосточных культур, пост натуфийских. Возможно, именно на языках культуры натуф и смежных говорили племена сероглазовской культуры и ее потомков в регионе Нижнего и Среднего Поволжья [38]. 


\begin{tabular}{|c|c|c|c|c|c|c|}
\hline Impact Factor: & $\begin{array}{l}\text { ISRA (India) } \\
\text { ISI (Dubai, UAE } \\
\text { GIF (Australia) } \\
\text { JIF }\end{array}$ & $\begin{array}{l}=1.344 \\
=0.829 \\
=0.564 \\
=1.500\end{array}$ & $\begin{array}{l}\text { SIS (USA) } \\
\text { PИНЦ (Russia) } \\
\text { ESJI (KZ) } \\
\text { SJIF (Morocco) }\end{array}$ & $\begin{array}{l}=0.912 \\
=0.234 \\
=1.042 \\
=2.031\end{array}$ & $\begin{array}{l}\text { ICV (Poland) } \\
\text { PIF (India) } \\
\text { IBI (India) }\end{array}$ & $\begin{array}{l}=6.630 \\
=1.940 \\
=4.260\end{array}$ \\
\hline
\end{tabular}

Восточная Европа в эпоху неолита

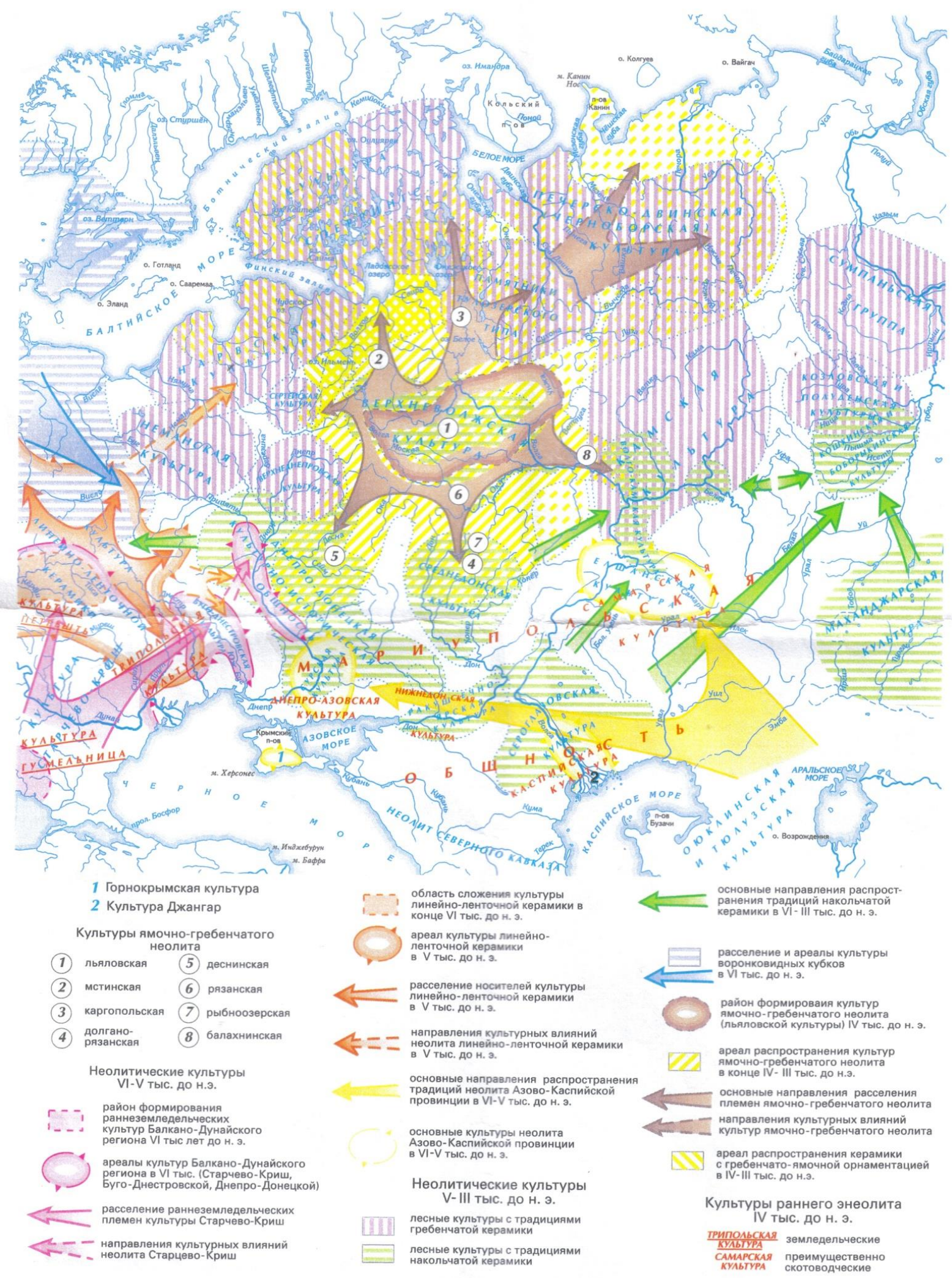

Карта 2 - Восточная Европа в эпоху неолита. Источник: [33, с 73].

ISPC Global Science,

Lancaster, USA 
Азово-каспийская миграция, обозначенная появлением елшанской и более ранних, еще мезолитических культур, связана с восточным регионом Средней Азии, расселением зарзийских племен на север после таянья ледника [39, с 153, c 197] и восточнее - за вычетом позднейших наслоений - смыкается с зоной расселения бурушаски тем времен, когда язык бурушаски еще не был реликтом. Все эти языковые группы - северокавказские семьи, кеты, бурушаски относятся к сино-кавказской общности ранга макросемьи, которую ряд современных палеогенетиков маркирует наличием мужских гаплогрупп R и Q [5].

В исходной зоне проживания зарзийских племен могло происходить смыкание с переднеазиатскими племенами и даже имел место дрейф генов. Этим можно объяснить наличие в афразийских языках синокавказского субстрата, согласно концепции А.Ю.Милитарева [40, с 390391], и распространение субклада R1b- V66 вплоть до Северной Африки и Испании (Els Trocs).

Соответственно, мы можем говорить о доиндоевропейской восточноевропейской степи как о пространстве, заселенном неолитическими племенами азово-каспийской общности, преимущественно синокавказскими по языку. С северо-запада или с юга в регион внедряются элементы,безусловно, ностратических общностей, в т.ч. которые упоминает А. Г. Козинцев и которые могли быть носителями индоевропейского языка.

Вопрос об исходном пункте проникновении в восточноевропейские степи носителей индоевропейского языка остается открытым: согласно мнению Л.С. Клейна - это северозападный маршрут, причем в случае новосвободнненцев, маркированный путем распространения гаплогруппы V, а в рамках гипотезы Иванова-Гамкрелидзе - южный (по мере проникновения индоевропейских племен в пределы майкопской протоцивилизации [41, с 916-918]), но в любом случаев в регионе степей Восточной Европы это пришлый элемент.

Мужские гаплогруппы палеолитической и мезолитической Европы - преимущественно I2, таким образом, особенно в случае северного варианта распространения индоевропейского языка, представляется вероятным, что носители ностратической компоненты имели значительный процент носителей гаплогруппы I2. Носители же субкладов R1a и R1b на определенных этапах истории могли говорить на языках синокавказской макросемьи.

Распространение сино-кавказских языков (особенно в доисторические времена) вызывает споры. Однако, кочевые и полукочевые народы, говорившие на синокавказских, и близких к ним языках известны. Выдвигались предположения, что на сино-кавказских языках говорили хурриты на западе Евразии (сейчас все больше аргументов о северокавказской принадлежности хурритского языка; по мнению Г.С. Старостина, поддержанному И.М. Дьяконовым [42]). Известны в историческое время и говорившие на вымершем ныне сино-тибетском языке кочевники-тангуты - на востоке Евразии [43] .В статье В.В.Иванова и Т.В.Гамкрелидзе «Индоевропейская прародина и расселение индоевропейцев: полвека исследований $и$ обсуждений» можно встретить следующее утверждение: «Согласно исследованиям А.П.Дульзона по характеру древних гидронимов дотюркское население Северного Казахстана было по языку енисейским (Дульзон 1962, 1968а, б; 1970) (а на Севере Казахстана известна кочевая ботайская культура). Финно-угорские группь $и$ находившиеся с ними в интенсивном контакте иранцы относятся к более поздним обитателям этих и более южных районов» [44].Вероятно, в степи существовал мощный сино-кавказский континуум, а затем (не ранее III тысячелетия до н.э.) подавляющая его часть была индоевропеизирована. Интересную привязку современных енисейских языков к древним языкам Евразии делает А.С.Касьян: «Генеалогическая атрибуция хаттского языка не установлена. Наиболее перспективным выглядит сопоставление с языками сино-кавказской макросемьи $и$ постулирование отдельной хаттской ветви внутри это макросемьи (причем Х. я. показывает спеиифическую близость скорее c енисейской и северо-кавказской ветвями нежели с сино-тибетской)» [45, с. 446]. При этом в статье [37, с. 317-318, 339, 343] автор особо подчеркивает близость хаттского с кетским. То есть наиболее вероятными наследниками «языков Центральной Азии» могут выглядеть хаттские и хурритские, кетский, бурушаски (учитывая гипотезу о карасукской семье). Идея о синокавказском характере носителей гаплогруппы R1 высказывались ранее - в статьях А. Клесова [65,66], А. Романчука [5], Ю. Мосенкиса [67]. 


\begin{tabular}{|c|c|c|c|c|c|c|}
\hline Impact Factor: & $\begin{array}{l}\text { ISRA (India) } \\
\text { ISI (Dubai, UAE } \\
\text { GIF (Australia) } \\
\text { JIF }\end{array}$ & $\begin{array}{l}=1.344 \\
=0.829 \\
=0.564 \\
=1.500\end{array}$ & $\begin{array}{l}\text { SIS (USA) } \\
\text { PИНЦ (Russia) } \\
\text { ESJI (KZ) } \\
\text { SJIF (Morocco) }\end{array}$ & $\begin{array}{l}=0.912 \\
=0.234 \\
=1.042 \\
=\mathbf{2 . 0 3 1}\end{array}$ & $\begin{array}{l}\text { ICV (Poland) } \\
\text { PIF (India) } \\
\text { IBI (India) }\end{array}$ & $\begin{array}{l}=6.630 \\
=1.940 \\
=4.260\end{array}$ \\
\hline
\end{tabular}

Приложение

Таблица 1

Местонахождение митохондриальных ДНК U5а в мезолите и неолите Евразии.

\begin{tabular}{|c|c|c|c|c|c|}
\hline $\begin{array}{l}\text { Культурная принадлежность } \\
\text { и местонахождение находок }\end{array}$ & Датировка & Y-DNA & mtDNA & Источник & $\begin{array}{l}\text { Количеств } \\
\text { о находок }\end{array}$ \\
\hline Blätterhöhle, Germany & $\begin{array}{l}8700-8600 \text { до } \\
\text { н.э. }\end{array}$ & & U5a & 26, p 480 & 1 \\
\hline Blätterhöhle, Germany & $\begin{array}{l}8700-8600 \text { до } \\
\text { н.э. }\end{array}$ & & U5a2c3* & 26, p 480 & 1 \\
\hline Chekalino & 7800 до н.э. & & U5a & 24, p 139 & 1 \\
\hline Lebyazhnika 1 & $\begin{array}{l}\text { VIII-VII } \\
\text { тысячелетия } \\
\text { до н.э. }\end{array}$ & & U5a1 & 24, p 139 & 1 \\
\hline $\begin{array}{l}\text { LesCloseaux } \\
\text { Malmaison) }\end{array}$ & 6900 до н.э. & & $\mathrm{U} 5 \mathrm{a} 2$ & 46, Table S4 & 1 \\
\hline Hohlenstein-Stadelcave & 6700 до н.э. & & U5a1 & 24, p 139 & 1 \\
\hline $\begin{array}{l}\text { Les Vignolles (Mareuil-lès- } \\
\text { Meaux) }\end{array}$ & 6300 до н.э. & & $\mathrm{U} 5 \mathrm{a} 2$ & 46, Table S4 & 1 \\
\hline $\begin{array}{ll}\text { Китойская } & \text { культура, } \\
\text { Lokomotiv, Irkutsk }\end{array}$ & $\begin{array}{l}6100-4900 \text { до } \\
\text { н.э. }\end{array}$ & & U5a & 25, p 44 & 2 \\
\hline Reuland-Loschbour & 6000 до н.э. & & U5a & 47, p 8, 17 & 1 \\
\hline FelsdachInzigofen, Germany & $\begin{array}{l}5900-5700 \text { до } \\
\text { н.э. }\end{array}$ & & U5a2c & 46, Table S4 & 1 \\
\hline Motala, Sweden & $\begin{array}{l}5900-5500 \text { до } \\
\text { н.э. }\end{array}$ & I2a1b* & U5a1 & 7, p 25 & 2 \\
\hline Motala, Sweden & $\begin{array}{l}\text { 5900-5500 до } \\
\text { н.э. }\end{array}$ & $\mathrm{I} 2 \mathrm{a} 1 *$ & U5a2d & 7, p 25 & 2 \\
\hline Motala, Sweden & $\begin{array}{l}5900-5500 \text { до } \\
\text { н.э. }\end{array}$ & I2a1a1a* & U5a2 & 7, p 25 & 1 \\
\hline SokRiver, Samara & $\begin{array}{l}5650-5550 \text { до } \\
\text { н.э. }\end{array}$ & R1b1a & U5a1d & 7, p 25 & 1 \\
\hline Южный Олений остров & 5500 до н.э. & & U5a & 48, p 4 & 1 \\
\hline Неолит Прибайкалья & & & U5a & 28, c 38 & 3 \\
\hline $\begin{array}{ll}\text { Елшанская } & \text { культура, } \\
\text { Lebyazhnika } 4 & \\
\end{array}$ & 5500 до н.э. & & $\begin{array}{l}\text { U5a1 } \\
\text { (условно) }\end{array}$ & 49 & 1 \\
\hline $\begin{array}{l}\text { Stora Förvar cave, Stora Karlsö } \\
\text { Island }\end{array}$ & $\begin{array}{l}5500-5250 \text { до } \\
\text { н.э. }\end{array}$ & & U5a1 & 50, p 747 & 1 \\
\hline Хвалынск-2 & $\begin{array}{l}5200-4000 \text { гг. } \\
\text { до н.э. }\end{array}$ & & U5a1i & 8 & 1 \\
\hline $\begin{array}{l}\text { Культура линейно-ленточной } \\
\text { керамики, Balatonsarszo }\end{array}$ & $\begin{array}{l}\text { V } \\
\text { тысячелетие } \\
\text { до н.э. } \\
\end{array}$ & $\mathrm{I} 1$ & U5a1a & 51, p 321 & 1 \\
\hline $\begin{array}{l}\text { Культура линейно-ленточной } \\
\text { керамики, Alsonyek-Bataszek }\end{array}$ & $\begin{array}{l}\text { V } \\
\text { тысячелетие } \\
\text { до н.э. }\end{array}$ & & U5a1 & $\begin{array}{l}\text { 51, p 256, p } \\
264, \text { p 321 }\end{array}$ & 1 \\
\hline Винча & $\begin{array}{l}\text { V } \\
\text { тысячелетие } \\
\text { до н.э. } \\
\end{array}$ & & U5a & 51, p 256, p 264 & 1 \\
\hline Винча & $\begin{array}{l}\text { V } \\
\text { тысячелетие } \\
\text { до н.э. } \\
\end{array}$ & & U5a1c & $\begin{array}{l}51, p 257-258 \\
265\end{array}$ & 1 \\
\hline Сопот & $\begin{array}{l}\mathrm{V} \\
\text { тысячелетие }\end{array}$ & & U5a & 51, p 258, 266 & 1 \\
\hline
\end{tabular}




\begin{tabular}{l|lr|ll|ll} 
& ISRA (India) & $=\mathbf{1 . 3 4 4}$ & SIS (USA) & $=\mathbf{0 . 9 1 2}$ & ICV (Poland) & $=\mathbf{6 . 6 3 0}$ \\
Impact Factor: & ISI (Dubai, UAE) & $=\mathbf{0 . 8 2 9}$ & PUHЦ (Russia) & $=\mathbf{0 . 2 3 4}$ & PIF (India) & $=\mathbf{1 . 9 4 0}$ \\
& GIF (Australia) & $\mathbf{0 . 5 6 4}$ & ESJI (KZ) & $=\mathbf{1 . 0 4 2}$ & IBI (India) & $=\mathbf{4 . 2 6 0}$ \\
& JIF & $\mathbf{1 . 5 0 0}$ & SJIF (Morocco) & $=\mathbf{2 . 0 3 1}$ & & \\
\hline
\end{tabular}

\begin{tabular}{|c|c|c|c|c|}
\hline & до н.э. & & & \\
\hline Lengyel & $\begin{array}{l}\text { V } \\
\text { тысячелетие } \\
\text { до н.э. }\end{array}$ & U5a & 51, p 257 & 1 \\
\hline $\begin{array}{l}\text { Днепро-донецкая культура, } \\
\text { Nikolskoye }\end{array}$ & 4200 до н.э. & U5a & 52, p 67 & 1 \\
\hline $\begin{array}{l}\text { Усть-тартасская } \\
\text { Sopka 2/3A, Sopka 2/4, }\end{array}$ & 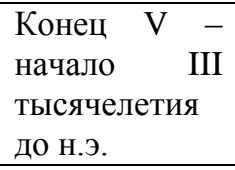 & U5a1 & 27, p 109 & 3 \\
\hline $\begin{array}{l}\text { Культура воронковидных } \\
\text { кубков, Ostorf, Germany }\end{array}$ & $\begin{array}{l}3200-3000 \text { до } \\
\text { н.э. }\end{array}$ & U5a & 24, p 139 & 1 \\
\hline $\begin{array}{l}\text { Культура ямочной керамики, } \\
\text { Visby, Sweden }\end{array}$ & $\begin{array}{l}3000-2400 \text { до } \\
\text { н.э. }\end{array}$ & U5a & 31, p 1758-1762 & 3 \\
\hline $\begin{array}{l}\text { Культура ямочной керамики, } \\
\text { Ajvide, Sweden }\end{array}$ & $\begin{array}{l}2800-2000 \text { до } \\
\text { н.э. }\end{array}$ & U5a1a'g & 31, p 1758-1762 & 2 \\
\hline Drestwo, Poland & 2250 до н.э. & U5a & 24, p 137-140 & 1 \\
\hline $\begin{array}{l}\text { Кротовская культура, Sopka } \\
2 / 5\end{array}$ & $\begin{array}{l}2200-1800 \text { до } \\
\text { н.э. }\end{array}$ & U5a & 27, p 109 & 2 \\
\hline $\begin{array}{l}\text { Кротовская культура, Sopka } \\
2 / 5\end{array}$ & $\begin{array}{l}2200-1800 \text { до } \\
\text { н.э. }\end{array}$ & U5a1 & 27, p 109 & 2 \\
\hline $\begin{array}{ll}\text { Андроновская } \\
\text { Tartas-1 }\end{array}$ & $\begin{array}{l}2000-1500 \text { до } \\
\text { Н.э. }\end{array}$ & U5a1 & 27, p 109 & 5 \\
\hline BolshoyOleniOstrov & 1500 до н.э. & U5a & $48, p 4$ & 2 \\
\hline BolshoyOleniOstrov & 1500 до н.э. & U5a1 & 48, p 4 & 4 \\
\hline
\end{tabular}

Таблица 2

Местонахождение митохондриальных ДНК U5b в мезолите и неолите Евразии.

\begin{tabular}{|c|c|c|c|c|c|}
\hline $\begin{array}{l}\text { Культурная принадлежность } \\
\text { и местонахождение находок }\end{array}$ & Датировка & Y-DNA & mtDNA & Источник & $\begin{array}{l}\text { Количеств } \\
\text { о находок }\end{array}$ \\
\hline Португалия & $\begin{array}{l}\text { Финальный } \\
\text { палеолит }\end{array}$ & & U5b1c1? & 53, pp. 781-86 & 1 \\
\hline Португалия & $\begin{array}{l}\text { Финальный } \\
\text { палеолит }\end{array}$ & & U5b1c2 & 53, pp. 781-86 & 1 \\
\hline Grotte du Bichon, Switzerland & $\begin{array}{l}13800-13500 \\
\text { до н.э. }\end{array}$ & $\mathrm{I} 2 \mathrm{a}$ & U5b1h & 54 & 1 \\
\hline $\begin{array}{l}\text { Мадленская } \\
\text { Оберкассель }\end{array}$ & 11400 до н.э. & & U5b1 & 55 & 1 \\
\hline Blätterhöhle, Germany & $\begin{array}{l}8700-8600 \text { до } \\
\text { н.э. }\end{array}$ & & U5b & 28, c 36 & 1 \\
\hline Blätterhöhle, Germany & 8800 до н.э. & & U5b2a2 & 26, p 480 & 1 \\
\hline FalkensteinerHöhlecave & 8200 до н.э. & & U5b2a & 24, p 139; 42 & 1 \\
\hline Hohlenstein-Stadel, Germany & 7800 до н.э. & & U5b2c1 & 24, p $139 ; 42$ & 1 \\
\hline Falkensteiner Höhlecave & 7200 до н.э. & & U5b2 & 24, p 139 & 1 \\
\hline L'abrides "Cabônes", France & 7000 до н.э. & & U5b1 & 46, Table S4 & 1 \\
\hline Hohlenstein-Stadelcave & 6700 до н.э. & & U5b2 & 24, p 139 & 1 \\
\hline Тарденуазская культура & 6600 до н.э. & & U5b1 & & 1 \\
\hline Кунда & 6350 до н.э. & & U5b2 & 24, p 139 & 1 \\
\hline Loschbour, Heffingen & $\begin{array}{l}6200-6000 \text { до } \\
\text { н.э. }\end{array}$ & I2a1b & U5b1a & $\begin{array}{l}24, \text { p 139; 46, } \\
\text { Table } 54 ; 51, \\
\text { p 47 }\end{array}$ & 1 \\
\hline Vela Spija & $\begin{array}{l}6200-6000 \text { до } \\
\text { н.э. }\end{array}$ & & U5b2a5 & $\begin{array}{l}51, \text { p 252, 254, } \\
262\end{array}$ & 1 \\
\hline $\begin{array}{l}\text { Vela Spila/Island Korčula, } \\
\text { Croatia }\end{array}$ & 6080 до н.э. & & U5b2a5 & 56, p 6 & 1 \\
\hline Яниславицкая культура & 6000 до н.э. & & U5b1b & 57 & 1 \\
\hline
\end{tabular}

ISPC Global Science,

Lancaster, USA 


\begin{tabular}{|c|c|c|c|c|c|c|}
\hline Impact Factor: & $\begin{array}{l}\text { ISRA (India) } \\
\text { ISI (Dubai, UAE } \\
\text { GIF (Australia) } \\
\text { JIF }\end{array}$ & $\begin{array}{l}=1.344 \\
=0.829 \\
=0.564 \\
=1.500\end{array}$ & $\begin{array}{l}\text { SIS (USA) } \\
\text { PUHЦ (Russia) } \\
\text { ESJI (KZ) } \\
\text { SJIF (Morocco) }\end{array}$ & $\begin{array}{l}=0.912 \\
=0.234 \\
=1.042 \\
=\mathbf{2 . 0 3 1}\end{array}$ & $\begin{array}{l}\text { ICV (Poland) } \\
\text { PIF (India) } \\
\text { IBI (India) }\end{array}$ & $\begin{array}{l}=6.630 \\
=1.940 \\
=4.260\end{array}$ \\
\hline
\end{tabular}

\begin{tabular}{|c|c|c|c|c|c|}
\hline GroßFredenwalde, Germany & 6000 до н.э. & & U5b & 58 & 2 \\
\hline La Braña-Arintero, Leon, Spain & 5900 до н.э. & $\begin{array}{l}\text { C1a2 } \\
\text { (одна из } \\
\text { находок) }\end{array}$ & U5b2c1 & 59, p 1494 & 2 \\
\hline GroßeOfnetHöhle, Germany & 5500 до н.э. & & U5b1d1 & 46 , Table S4 & 1 \\
\hline LesFontinettes, France & 5400 до г.э. & & U5b1b & 46 , Table $S 4$ & 1 \\
\hline Bockstein Höhle, Germany & 5400 до н.э. & & U5b1d1 & 46, Table $S 4$ & 1 \\
\hline Винча & $\begin{array}{l}5300-5000 \text { до } \\
\text { Н.э. }\end{array}$ & & U5b1b1 & $\begin{array}{l}\text { 51, p 253, 257- } \\
258,265\end{array}$ & 1 \\
\hline Aizpea (Navarre) & 4600 до н.э. & & U5b1 & 55 & 1 \\
\hline Lengyel, Borjad Kenderfoldek & $\begin{array}{l}\text { V } \\
\text { тысячелетие } \\
\text { до н.э. }\end{array}$ & & U5b & $\begin{array}{l}51, \text { p } 258-259, \\
266,268,321\end{array}$ & 3 \\
\hline Нарвская культура, Kretuonas & 4450 до н.э. & & U5b2 & 24, p 139 & 2 \\
\hline $\begin{array}{l}\text { Le Vieux Tordoir (Berry-au- } \\
\text { Bac), France }\end{array}$ & 4300 до н.э. & & U5b1a & 46, Table S4 & 1 \\
\hline Нарвская культура, Kretuonas & 4200 до н.э. & & U5b & 24, p 139 & 1 \\
\hline Культура Цедмар, Dudka & $\begin{array}{l}\text { IV } \\
\text { тысячелетие } \\
\text { до н.э. }\end{array}$ & & U5b1 & 24, p 139 & 2 \\
\hline Alto de Reinoso & 3700 до н.э. & & U5b2b3 & 60, p 7 & 4 \\
\hline Alto de Reinoso & 3700 до н.э. & & U5b3 & 60, p 7 & 1 \\
\hline Alto de Reinoso & 3700 до н.э. & & U5b & $61, \mathrm{p} 8$ & 1 \\
\hline $\begin{array}{l}\text { Культура } \\
\text { керамики Treilles, Frapдесе }\end{array}$ & 3000 до н.э. & & U5b1c & $\begin{array}{l}\text { 61, p } 9788- \\
\text { 9791 }\end{array}$ & 1 \\
\hline $\begin{array}{l}\text { Культура ямочной керамики, } \\
\text { Ajvide, Sweden }\end{array}$ & $\begin{array}{l}2800-2000 \text { до } \\
\text { н.э. }\end{array}$ & & U5b & 31, p 1758-1762 & 1 \\
\hline $\begin{array}{l}\text { Культура ямочной керамики, } \\
\text { Ajvide, Sweden }\end{array}$ & $\begin{array}{l}2800-2000 \text { до } \\
\text { н.э. }\end{array}$ & & U5b2b1a & 31, p 1758-1762 & 1 \\
\hline $\begin{array}{l}\text { Культура ямочной керамики, } \\
\text { Fridtorp, Sweden }\end{array}$ & $\begin{array}{l}2800-2000 \text { до } \\
\text { н.э. }\end{array}$ & & U5b & 31, p 1758-1762 & 1 \\
\hline
\end{tabular}

Таблица 3

Местонахождение митохондриальных ДНК V в мезолите, неолите и энеолите Евразии.

\begin{tabular}{|c|c|c|c|c|c|}
\hline $\begin{array}{l}\text { Культурная принадлежность } \\
\text { и местонахождение находок }\end{array}$ & Датировка & Y-DNA & mtDNA & Источник & $\begin{array}{l}\text { Количеств } \\
\text { о находок }\end{array}$ \\
\hline $\begin{array}{l}\text { Мадленская культура, } \\
\text { Франция, север Испании }\end{array}$ & $\begin{array}{l}15000-8000 \\
\text { до н.э. }\end{array}$ & & $\mathrm{V}$ & 18, p 1146 & 1 \\
\hline Португалия & $\begin{array}{l}\text { Финальный } \\
\text { палеолит }\end{array}$ & & V10a & 53, pp. 781-86 & 1 \\
\hline Taforalt Cave, север Марокко & 10000 до н.э. & & $\begin{array}{l}\mathrm{V} 1 *, \quad \mathrm{~V} 3 \\
\mathrm{~V} 6, \mathrm{~V} 7, \mathrm{~V} 9\end{array}$ & 62 & 5 \\
\hline $\begin{array}{l}\text { Сумнагинская } \begin{array}{r}\text { культура, } \\
\text { Жохово, } \\
\text { острова }\end{array} \\
\end{array}$ & $\begin{array}{l}6200-5500 \text { до } \\
\text { н.э. }\end{array}$ & & $\mathrm{V}$ & 21, c 66 & 1 \\
\hline $\begin{array}{l}\text { Культура линейно-ленточной } \\
\text { керамики, Alsonyek-Bataszek, } \\
\text { Balatonsarszo }\end{array}$ & $\begin{array}{l}\text { V } \\
\text { тысячелетие } \\
\text { до н.э. } \\
\end{array}$ & $\mathrm{E}$ & V3a & 51, p 321 & 1 \\
\hline Lengyel & $\begin{array}{l}\mathrm{V} \\
\text { тысячелетие } \\
\text { до н.э. } \\
\end{array}$ & & $\mathrm{HV}$ & 51, p 259, p 268 & 1 \\
\hline Рессенская культура & $\begin{array}{l}4600-3900 \text { до } \\
\text { н.э. }\end{array}$ & & $\mathrm{V}$ & 19, p 95-96 & 1 \\
\hline Готланд & Неолит & & $\mathrm{V}$ & 31 & 1 \\
\hline $\begin{array}{l}\text { Культура линейно-ленточной } \\
\text { керамики, }\end{array}$ & $\begin{array}{l}4500-3500 \text { до } \\
\text { н.э. }\end{array}$ & & $\mathrm{V}$ & 19, p 95-96 & 1 \\
\hline
\end{tabular}


Impact Factor:

\begin{tabular}{|c|c|c|}
\hline ISRA (India) & $=1.344$ & SIS (USA) \\
\hline ISI (Dubai, UAE & 0.829 & РИНЦ $($ Russia $)=0.234$ \\
\hline tralia) & $=0.564$ & ESJI (KZ) \\
\hline & $=1.500$ & SJIF (Morocco) \\
\hline
\end{tabular}

\begin{tabular}{|c|c|c|c|c|}
\hline \multicolumn{5}{|l|}{ Европа } \\
\hline Зальмюндская культура & $\begin{array}{l}4100-3900 \text { до } \\
\text { н.э. }\end{array}$ & $\mathrm{V}$ & 19, p 95-96 & 1 \\
\hline Alto de Reinoso & 3700 до н.э. & $\mathrm{V}$ & 61, p 7 & 1 \\
\hline $\begin{array}{l}\text { Новосвободненская культура, } \\
\text { Северный Кавказ }\end{array}$ & $\begin{array}{l}3500-3100 \text { до } \\
\text { н.э. }\end{array}$ & V7 & 17, c 38 & 1 \\
\hline $\begin{array}{l}\text { Зальцмюндская культура, } \\
\text { Центральная Германия }\end{array}$ & $\begin{array}{l}3400-3100 \text { до } \\
\text { н.э. }\end{array}$ & $\mathrm{V}$ & $\begin{array}{l}\text { 63, } \\
\text { Supplementary } \\
\text { Materials, p } 30\end{array}$ & 1 \\
\hline $\begin{array}{l}\text { Культура ямочной керамики, } \\
\text { Южная Скандинавия }\end{array}$ & $\begin{array}{l}3300-2800 \text { до } \\
\text { Н.э. }\end{array}$ & $\mathrm{V}$ & 19, p 95-96 & 1 \\
\hline $\begin{array}{l}\text { Бернбургская к культура, } \\
\text { Центральная Германия }\end{array}$ & $\begin{array}{l}3100-2600 \text { до } \\
\text { н.э. }\end{array}$ & $\mathrm{V}$ & $\begin{array}{l}\mathbf{6 3}, \\
\text { Supplementary } \\
\text { Materials, p } 30\end{array}$ & 1 \\
\hline $\begin{array}{ll}\text { Трипольская } & \text { культура, } \\
\text { Украина, Румыния } & \\
\end{array}$ & $\begin{array}{l}3000-2500 \text { до } \\
\text { н.э. }\end{array}$ & V & 64, с 14 & 2 \\
\hline
\end{tabular}

\section{References:}

1. Linguistic encyclopedia. M.,1990. Article «Indoeuropeistics».

2. (2016)

Available: https://www.academia.edu/23862173/\%D0\%9E $\% \mathrm{D} 0 \% \mathrm{BD} \% \mathrm{D} 0 \% \mathrm{~B} 0 \% \mathrm{D} 1 \% 87 \% \mathrm{D} 0 \% \mathrm{~B} 0 \% \mathrm{D} 0$ $\% \mathrm{BB} \% \mathrm{D} 1 \% 8 \mathrm{C} \% \mathrm{D} 0 \% \mathrm{BD} \% \mathrm{D} 0 \% \mathrm{BE} \% \mathrm{D} 0 \% \mathrm{BC}$ $\% \mathrm{D} 1 \% 8 \mathrm{D} \% \mathrm{D} 1 \% 82 \% \mathrm{D} 0 \% \mathrm{~B} 0 \% \mathrm{D} 0 \% \mathrm{BF} \% \mathrm{D} 0$ $\% \mathrm{~B} 5 \% \mathrm{D} 0 \% \mathrm{~B} 8 \% \mathrm{D} 0 \% \mathrm{BD} \% \mathrm{D} 0 \% \mathrm{~B} 4 \% \mathrm{D} 0 \% \mathrm{BE}$ $\% \mathrm{D} 0 \% \mathrm{~B} 5 \% \mathrm{D} 0 \% \mathrm{~B} 2 \% \mathrm{D} 1 \% 80 \% \mathrm{D} 0 \% \mathrm{BE} \% \mathrm{D} 0 \%$ BF\%D0\%B5\%D0\%B9\%D1\%81\%D0\%BA\%D 0\%BE\%D0\%B9 \%D0\%B8\%D1\%81\%D1\%82 \%D0\%BE\%D1\%80\%D0\%B8\%D0\%B8 2016 - On the initial_stage of Indo-

European_history 2016

(Accessed: 10.04.2016).

3. (2016)

Available: http://генофонд.pф/?page id=7979\&cpage=1\# comment-2949 (Accessed: 10.04.2016).

4. Dergachev VI (2007) On Sceptres, Horses and War. Studies in the defense of the migration concept of M. Gimbutas. Sankt-Peterburg: Nestor-Istoriya, 2007.

5. Romanchuk AA, Semenov AS (2014) R and Q haplogroups of Y-chromosome and Proto-North Caucasian Substratum of Proto-Indo-Europeans // Russian Journal of Biological Research, 2014, Vol. (1), № 1, pp. 46-68 .

6. IainMathieson, et al. (2016) Eight thousand years of natural selection in Europe. doi:http://dx.doi.org/10.1101/016477

7. Haak W, et al. (2015) Massive migration from the steppe is a source for Indo-European languages in Europe, bioRxiv preprint.

8. Mathieson I, et al. (2015) Eight thousand years of natural selection in Europe, biovix preprint March 14, 2015; update 10 October 2015.
9. Alexander S. Semenov, Vladimir V. Bulat (2016) Possible North-Eastern Connections of the R1a1-populations of Corded Ware Culture According to the Archaeologic and Paleogenetic Data. Russian Journal of Biological Research, 2015, Vol. (5).

10. Mudrak OA (2013) Comparative-historical research on the linguistic situation in Northeast Asia. M., 2013.

11. Forrer E (1934) Neue Problemezum Ursprung der indogermanichen Sprachen. «Mannus», B. 26, 1934

12. Gornung BV (1964) K voprosu ob obrazovanii indoevropeyskoi yazykovoy obschnosti. M., 1964.

13. Kortlandt F (2016) 2004b Indo-Uralic consonant gradation. Etymologie, Entlehnungen und Entwicklungen [Fs. Koivulehto] (Helsinki: SociétéNéophilologique). // Leiden University - www.kortlandt.nl

14. Starostin G (2016) Proto-Indo-European and Proto-Uralic among other proto-languages of Eurasia: a lexicostatistical evaluation. Available:

https://www.academia.edu/13841521/ProtoIndo-European_and_Proto-

Uralic_among_other_proto-

languages_of_Eurasia_a_lexicostatistical_evalu ation (Accessed: 10.04.2016).

15. Kleyn LS (2007) Ancient Migrations and the Ethnogenesis of Indo-European Peoples. St. Petersburg., 2007.

16. Rezepkin AD (2004) Some aspects of the early bronze formation in the North Caucasus // Materials and research on Kuban archaeology. Krasnodar, 2004. Vol.4. 


\begin{tabular}{|c|c|c|c|c|c|c|}
\hline Impact Factor: & $\begin{array}{l}\text { ISRA (India) } \\
\text { ISI (Dubai, UAF } \\
\text { GIF (Australia) } \\
\text { JIF }\end{array}$ & $\begin{array}{l}=1.344 \\
=0.829 \\
=0.564 \\
=1.500\end{array}$ & $\begin{array}{l}\text { SIS (USA) } \\
\text { PИНЦ (Russia) } \\
\text { ESJI (KZ) } \\
\text { SJIF (Morocco) }\end{array}$ & $\begin{array}{l}=0.912 \\
=0.234 \\
=1.042 \\
=\mathbf{2 . 0 3 1}\end{array}$ & $\begin{array}{l}\text { ICV (Poland) } \\
\text { PIF (India) } \\
\text { IBI (India) }\end{array}$ & $\begin{array}{l}=6.630 \\
=1.940 \\
=4.260\end{array}$ \\
\hline
\end{tabular}

17. V. Nedoluzhko, E. S. Boulygina, A. S. Sokolov, S. V. Tsygankova, N. M. Gruzdeva, A. D. Rezepkin, and E. B. Prokhortchouk (2014) Analysis of the Mitochondrial Genome of a Novosvobodnaya Culture Representative using Next-Generation Sequencing and Its Relation to the Funnel Beaker Culture. Acta Naturae v.6(2); Apr-Jun 2014. 18.

18. Antonio Torroni, et al. (1998) mtDNA Analysis Reveals a Major Late Paleolithic Population Expansion from Southwestern to Northeastern Europe, American Journal of Human Genetics, vol. 62 (1998).

19. Anna Szécsényi-Nagy (2015) Molecular genetic investigation of the Neolithic population history in the western Carpathian Basin. 2015.

20. W. Meier-Arendt (1974) ZurFrage der Genese der RössenerKultur.In: Germania.52/1, 1974, 115.

21. Pitulko VV, Khartanovich VI., Timoshin V. B., Chasnyk V. G., Pavlova E. Yu., Kasparov A. K. (2015) Drevneyshie antropologicheskie nahodki vy'sokoshirotnoy Arktiki (Johovskaya stoyanka, Novosibirskie o-va) (Oldest anthropological finds from the high-latitude Arctic [Zhokhov site, ew Siberia archipelago]) // Ural'skiy istoricheskiy vestnik (Uralian historical herald). 2015. No. 2 (47). P. 62-73 (in Russian)

22. Pettitt Paul, White Mark (2012) The British Palaeolithic: Human Societies at the Edge of the Pleistocene World. Abingdon, UK: Routledge. ISBN 978-0-415-67455-3

23. A.Achilli, et al. (2005) Saami and Berbers-An Unexpected Mitochondrial DNA Link. Am. J. Hum. Genet. 76:883-886, 2005

24. Bramanti B, Thomas MG, Haak W, Unterlaender $\mathrm{M}$, Jores $\mathrm{P}$, Tambets $\mathrm{K}$, Antanaitis-Jacobs I, Haidle MN, Jankauskas R, Kind CJ, Lueth F, Terberger T, Hiller J, Matsumura S, Forster P, Burger J. (2009) Genetic discontinuity between local huntergatherers and central Europe's first farmers. Scienc. 2009 Oct 2;326(5949):137-40. doi: 10.1126/science.1176869. Epub 2009 Sep 3.

25. Mooder K, et al. (2006) Population Affinities of Neolithic Siberians: A Snapshot From Prehistoric Lake Baikal, American Journal of Physical Anthropology, vol. 129, no. 3 (March 2006), pp. 323-481.

26. Bollongino R, et al. (2013) 2000 years of parallel societies in Stone Age Central Europe, Science, Online October 102013.

27. Vyacheslav I (2012) Molodinetal.Human migrations in the southern region of the West Siberian Plain during the Bronze Age: Archaeological, palaeogenetic and anthropological data. 2012
28. Trapezov RO (2014) Genetic structure of the populations of the south Siberia in Neolithic and early Bronze Ages (VI- beginning of III mil. BC). Novosibirsk, 2014.

29. (2014) Populationsgenetikkupfer- und bronzezeitlicher Bevölkerungen der osteuropäischen Steppe Dissertation zur Erlangung des Grades Doktor der Naturwissenschaften Mainz 2014.

30. (2016) http://suyun.info/index.php?p=ancientdna (Accessed: 10.04.2016).

31. Malmström, H. et al. (2015) Ancient mitochondrial DNA from the northern fringe of the Neolithic farming expansion in Europe sheds light on the dispersion process, Phil. Trans. R. Soc. B, vol. 370, no. 1660, 20130373

32. Clio Der Sarkissian, Oleg Balanovsky, Guido Brandt, Valery Khartanovich, Alexandra Buzhilova, Sergey Koshel, Valery Zaporozhchenko, Detlef Gronenborn, Vyacheslav Moiseyev, Eugen Kolpakov, Vladimir Shumkin, Kurt W. Alt, Elena Balanovska, Alan Cooper, Wolfgang Haak, Genographic Consortium, and Theodore G. Schurr (2013) Ancient DNA Reveals Prehistoric Gene-Flow From Siberia in the Complex Human Population History of North East Europe, 2013.

33. (2005) Tartarica. Atlas. Kazan, 2005.

34. Safronov V.A., Nikolaeva N.A (2016) Carpatian-Polessye urheimat of the Eurasians and the separation of the Western Eurasians and their migration to Anatolia. http://slavya.ru/trad/history/genezis/safronov/pr a rodina.htm\#Cont

35. Romanchuk A.A. (2016) The Eastern Eurasian hyphothesis of dene-caucasian urheimat according to genetic geographical data- the attempt of synthesis. Available: http://генофонд.pф/?page_id=4366 (Accessed: 10.04.2016).

36. Balanovskiy O (2016) Genogeographical distribution of the Y-DNA chromosome in Europe. Available: http://генофонд.pф/?page id=5629 (Accessed: 10.04.2016)

37. Kassian A (2009) Hattic as a Sino-Caucasian Language.// UGARIT-FORSCHUNGEN. Internationales Jahrbuch fur die Altertumskunde Syrien-Palastinas. Band 41, 2009.

38. Melentiev AN (1977) Mesolithic of the Northern Caspian Area (Seroglazovo archaeological sites). // KSIA 149. 1977.

39. (1989) Mesolithic of the USSR. M., 1989.

40. Starostin GS (2015) Back to the origins of linguistic diversification. M.,2015. 


\begin{tabular}{|c|c|c|c|c|c|c|}
\hline Impact Factor: & $\begin{array}{l}\text { ISRA (India) } \\
\text { ISI (Dubai, UAE } \\
\text { GIF (Australia) } \\
\text { JIF }\end{array}$ & $\begin{array}{r}=1.344 \\
=0.829 \\
=0.564 \\
=1.500\end{array}$ & $\begin{array}{l}\text { SIS (USA) } \\
\text { PИНЦ (Russia) } \\
\text { ESJI (KZ) } \\
\text { SJIF (Morocco) }\end{array}$ & $\begin{array}{l}=0.912 \\
=0.234 \\
=1.042 \\
=\mathbf{2 . 0 3 1}\end{array}$ & $\begin{array}{l}\text { ICV (Poland) } \\
\text { PIF (India) } \\
\text { IBI (India) }\end{array}$ & $\begin{array}{l}=6.630 \\
=1.940 \\
=4.260\end{array}$ \\
\hline
\end{tabular}

41. Gamkrelidze TV, Ivanov VV (1984) Indoevropejskij jazyk i indoevropejcy. 2 vols. Tbilisi: Izdatel'stvo Tbilisskogo Universiteta, 1984.

42. Diakonov IM (1967) Languages of the Ancient Near East. M., 1967.

43. van Driem, George (2001) Handbuch Der Orientalistik.

44. Ivanov V.V., Gamkrelidze T.V (2013) Indoevropeiskaya prarodina $\mathrm{i}$ rasselenie indoevropeitsev: polveka issledovanii $i$ obsuzhdenii. Voprosy yazykovogo rodstva, 9 (2013). pp. 109-136. http://www.jolr.ru/files/(110)jlr2013-9(109136).pdf.

45. Kas'yan AS (2010) Leksicheskie kontakty khattskogo yazyka.// Indoevropeiskoe yazykoznanie i klassicheskaya filologiya XIV. Materialy chtenii, posvyashchennykh pamyati professora Iosifa Moiseevicha Tronskogo. 21-23 June 2010. SPb., 2010.

46. Posth, C. et al. (2016) Pleistocene mitochondrial genomes suggest a single major dispersal of non-Africans and a Late Glacial population turnover in Europe, Current Biology, published online February 4, 2016

47. Dominique Delsate, Jean Michel Guinet et Steven Saverwyns. (2009) De l'ocre sur le crâne mésolithique (haplogroupe U5a) de Reuland-Loschbour (Grand-Duché de Luxembourg)? Bull. Soc. Préhist. Luxembourgeoise 31, 2009, 7-30.

48. Lazaridis, I. et al. (2013) Ancient human genomes suggest three ancestral populations for Europeans, pre-print online 23 December 2013.

49. Der Sarkissian. etal. Ancient DNA Reveals Prehistoric Gene-Flow From Siberia in the Complex Human Population History of North East Europe. 2011 Available: http://repository.upenn.edu/cgi/viewcontent.cgi ?article $=1038 \&$ context $=$ anthro_papers

(Accessed: 10.04.2016).

50. Skoglund, P. et al. (2014), Genomic diversity and admixture differs for Stone-Age Scandinavian foragers and farmers, Science, Published Online April 242014.

51. Szécsényi-Nagy A (1984) Molecular genetic investigation of the Neolithic population history in the western Carpathian Basin. Molekulargenetische Untersuchungen zur Bevölkerungsgeschichte des Karpatenbeckens. Dissertation zur Erlangung des Grades. "Doktor der Naturwissenschaften". geb. am 08. April 1984 in Budapest.

52. Newton, Jeremy R (2011) "Ancient Mitochondrial DNA From Pre-historic Southeastern Europe: The Presence of East Eurasian Haplogroups Provides Evidence of Interactions with South Siberians Across the
Central Asian Steppe Belt" (2011). Masters Theses. Paper 5.

53. Chandler, H., Sykes, B. and Zilhão, J. (2005) Using ancient DNA to examine genetic continuity at the Mesolithic-Neolithic transition in Portugal, in P. Arias, R. Ontanon and C. Garcia-Monco (eds.), Actas del III Congreso del Neoliticoen la Peninsula Iberica, pp. 78186.

54. Jones, E. R. et al. (2016) Upper Palaeolithic genomes reveal deep roots of modern Eurasians, Nature Communications, 6, article number: 8912

55. Hervella $\mathrm{M}$, Izagirre $\mathrm{N}$, Alonso $\mathrm{S}$, Fregel R, Alonso A, et al. (2012) Ancient DNA from Hunter-Gatherer and Farmer Groups from Northern Spain Supports a Random Dispersion Model for the Neolithic Expansion into Europe. PLoS ONE 7(7): 10.1371/annotation/3dac0b4ff76e-4bc1-8559-acb41b87b02c. doi: 10.1371/annotation/3dac0b4f-f76e-4bc1-8559acb41b87b02c

56. Szécsényi-Nagy A. et al. (2015), Tracing the genetic origin of Europe's first farmers reveals insights into their social organization, Proceedings of the Royal Society B, vol. 282, no. $1805,20150339$.

57. Stanaszek, L. and Mankowska-Pliszka, H. (2013), Nowe spojrzenie na „człowieka z Janisławic”. Analiza antropologiczna-kliniczna szkieletu,

https://pbn.nauka.gov.pl/works/442953

58. Terberger, T. et al. (2015) Standing upright to all eternity -The Mesolithic burial site at GroßFredenwalde, Brandenburg (NE Germany), Quartär 6, pp. 133-153.

59. Sánchez-Quinto, F. et al. (2012), Genomic affinities of two 7,000-year-old Iberian huntergatherers, Current Biology, Available online 28 June 201

60. Alt KW, Zesch S, Garrido-Pena R, Knipper C, Szécsényi-Nagy A, Roth C, et al. (2016) A Community in Life and Death: The Late Neolithic Megalithic Tomb at Alto de Reinoso (Burgos, Spain). PLoS ONE 11(1): e0146176. doi:10.1371/journal. pone.0146176.

61. Lacan M. et al. (2011) Ancient DNA reveals male diffusion through the Neolithic Mediterranean route. Edited by Colin Renfrew, University of Cambridge, Cambridge, United Kingdom, and approved May 2, 2011 (received for review January 19, 2011)

62. (2016) Available: http://gentis.ru/info/mtdnatutorial/hg-v/v (Accessed: 10.04.2016).

63. Guido Brandt et al. (2013) Ancient DNA reveals key stages in the formation of Central European mitochondrial genetic diversity. Science. 2013 Oct 11; 342(6155): 257-261. doi: $10.1126 /$ science. 1241844 


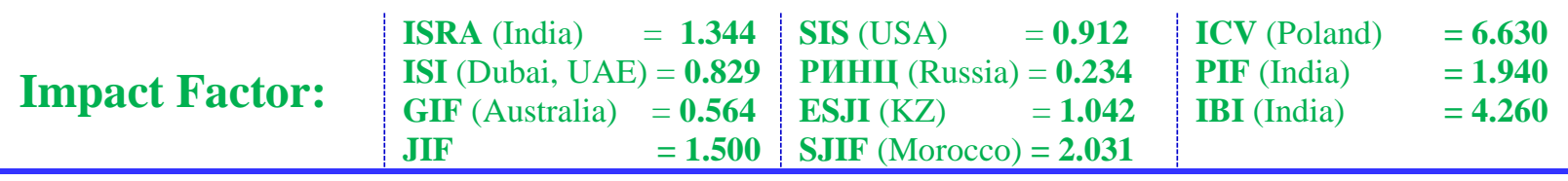

64. Alexey G. Nikitin, Mykhailo P. Sokhatsky, Mykola M. Kovaliukh, Mykhailo Y. Videiko (2010) Comprehensive Site Chronology and Ancient Mitochondrial DNA Analysis from Verteba Cave -a Trypillian Culture Site of Eneolithic Ukraine. IANSA 2010.

65. (2016)

Available: http://pereformat.ru/2014/04/arbins/ (Accessed: 10.04.2016).
66. (2016)

Available: http://pereformat.ru/2014/05/arbins-2/ (Accessed: 10.04.2016).

67. (2016)

Available: https://www.academia.edu/20658780/IndoEuropeanization of Europe an interdisciplinar y_scenario (Accessed: 10.04.2016). 